\title{
D. E. Min's Creative Work in the History of the Russian Literary Translation of the XIXth Century
}

\author{
Dmitry Nikolayevich Zhatkin \\ Department of Translation and Methods of Translation, Penza State Technological University, \\ Penza, Russian Federation
}

\section{Olga Sergeevna Milotaeva}

Department of Foreign Languages of the Penza State University of Architecture and Construction, Penza, Russian Federation

\section{Doi:10.5901/mjss.2015.v6n3s3p383}

\section{Abstract}

In the article devoted to the creative activity of the prominent Russian translator Dmitry Egorovich Min (1818 - 1883), his contribution to the history of Russian poetic translation, development of theoretical representations in the field of the Russian translated fiction is for the first time completely comprehended. Without being engaged in the original literary creativity, D.E. Min saw the main objective in the complete and exact reflection of specifics of foreign works in Russian. Such approach which didn't correspond to characteristic tendency of the translation development in the 1850 - 1880s as a free interpretation, limited possibilities of Russian translation as the phenomena of native literature, but thus allocated it with the essential philological importance, fundamental validity that, finally, allowed Min to occupy a unique position in Russian literature and culture of the time. The choice of works for the translation was inevitably caused by ideological positions of D.E. Min which were rather inconsistent and didn't allow him to be considered a translator of "pure art" as well as a number of their opponents from democratic literary circles. D.E. Min for many years holding high positions in Moscow University and having the solid social status, generally cooperated with the extremely right in ideology "Russkiy Vestnik" ("Russian Messenger") of M. N. Katkov, but thus quite often interpretated the works proclaiming ideas of social justice, need of education of common people at large etc. In this regard the choice of Min of J. Krabb's works is interesting representing the god-loving and law-abiding priest who was capable to describe truthfully in the poems cruelty of the world, burden of country work, disgrace and injustice of the strong, their indifference to sufferings of people; also the personality of R.-U. Buchanan translated by D.E. Min is so inconsistent combining loyalty of the power and internal rejection of public processes. D.E. Min for the first time in Russia addressed to creative works of the English social democrat U. Morris but chose for the translation the most neutral, the work deprived of revolutionary pathos - the poem "Earthly paradise", literary stylization created under the influence of the Pre-Raphaelite Dante Gabriel Rossetti and representing reality in an allegorical form. Noting discrepancy of ideological searches of D. E. Min, the authors of the article bring to thought of illegality of the characteristic of the 1860s - the 1870s only as the fight stage between noble and liberal and revolutionary-democratic directions in the Russian literary translation, note existence of such figures in literary process of that time which managed to avoid direct participation in the called polemic on positions of one of the parties. Avoiding distortions towards literalism and a liberty, seeking for the most exact preservation and reconstruction of realities of other cultures, the nonprofessional translator, the scientist-physician D. E. Min made the significant contribution to professionalizing of translation matter in Russia.

Keywords: D.E. Min, Russian-English literary and historical and cultural communications, poetic translation, comparative study, reminiscence, tradition, cross-cultural communication, art detail

\section{Introduction}

Poetic creative work was a "private" aspect of life of a professor of medicine D. E. Min proceeding in parallel with his official biography inseparably linked with Moscow University where he passed the way from an assistant of a university hospital clinic to a professor of the forensic medicine department, a secretary of medical faculty, periodically acting as a rector and a trustee of the educational district (Levin, 1999). Min translated from three European languages - the Italian, German and English languages, and from the very beginning set for himself complex challenges, significant for Russian poetic translation. The translation of fragments of "Hell" from "The divine comedy" of Dante Alighieri which was issued in 1843 became his first publication. Min strictly adhered to the requirements to the translation existing at that time, in particular the canon established by A.S. Pushkin - need of observance of terza rimas (Dzhivelegov, 1933). 
During Min's translation activity (1840s - the first half of 1880s) the area of the poetic translation, in I.G. Yampolsky's opinion, reached "exclusive blossoming in a quantitative as well as in qualitative sense" (Yampolsky, 1956). Also the writers winning to themselves fame by original creative works (A.K. Tolstoy, A.N. Pleshcheev, A.N. Maykov, A.A. Fet, A.V. Druzhinin, L.A. May, M.L. Mikhaylov, V.S. Kurochkin, D.D. Minayev, I.P. Kreshev, etc.), and those whose translation creativity prevailed over all the rest (P.I. Veynberg, D.L. Mikhalovsky, N.V. Berg, P.A. Kozlov, etc.) were engaged in the translation, and, at last, actually the translators who didn't have or having the small number of original works (D.E. Min, N.V. Gerbel, N.H. Katcher, A.L. Sokolovsky, etc.). The circle of the translated authors was also extraordinary wide - Antique, East, Slavonic, Italian, German, English, French. The researchers of the history of Russian translation L.L.Nelyubin and G.T. Hukhuni see the reasons of sharp proliferation of translated works in Russia in the processes of liberalization in society the consequence of which became professionalizing of translation creative work, however they made remarks about the quality decline of the translations in practice (Nelyubin \& Hukhuni, 2008).

The works of certain foreign poets (first of all, G.Heine, P.-J.Bérenger) became the object of collision of different poetic currents in Russia of the second half of the XIXth century (Staritsyna, 1980; Gordon, 1973; Gordon, 1979). Representatives of poetic school of "pure art" aestheticized the translations of foreign language works whereas poets and translators of the democratic school, on the contrary, used their pithiness and emotional effectiveness for advance of their own views, the civic position. This rivalry of the directions, undoubtedly, enriched the Russian art word and poetic skill because collision of two extreme translation methods - sensationalism and literalism - led to the formulation of new requirements to a poetic translation the problem of which is successfully expressed by P.M.Toper: "If the translation doesn't become the fact of native literature, it won't be perceived as a work of art. If it doesn't remain the work of other people - it will stop being the translation" (Toper, 2001). In the light of that is told need of not only the emergence of the first scientific work devoted to Min-translator's principles, but also justifications of these principles taking into account rivalry of various directions and translation methods is represented obvious.

\section{Literature Review}

The outstanding researcher of the theory and history of the translation A.V.Fedorov, recognizing influence of ideological and political fight of the second half of the XIXth century on the translation, nevertheless in the 1960s rejected the categorical division of the translations dominating in native literary criticism in good, revolutionary-democratic and bad, noble and liberal. He recognized that "it isn't always possible with full persuasiveness to establish natural connection between political sympathies and features of a translator's work", but at the same time noted that "in some cases this communication acts absolutely distinctly and directly" (Fedorov, 1983a). This connection was shown as in specifics of interests in the field of foreign-language literature as well as in distinction of translation methods and tendencies. A.A.Fet,

L.A.Mey, A.K.Tolstoy's translations at distinction of their art advantages are characterized in general by great attention to a formal originality of the original (to a metre, a rhyme and so on), by separate art details; V.S.Kurochkin's translations of Bérenger, on the contrary, abound with derogations from the original up to the russification proved by desire of transferring of foreign-language work as complete, capable to cause associations, habitual for the reader (Fedorov, 1983b). Despite emphasized aspiration to literalism in the translation from many representatives of "pure art" (for example, A.A.Fet), certain translators differed in the individual approach to the interpreted works. So, it is possible to note A.K.Tolstoy's approach conditionally impressionistic, - translating "Corinthian bride" of Goethe, he formulated the principles this way: "... it isn't necessary to translate words, and even sometimes sense, and it is necessary to transfer impression" (Levin \& Fedorov, 1960). In a similar way also the poet of the democratic school V.S. Kurochkin who received N.A.Dobrolyubov's reproach that "absolutely in vain inserted into Bérenger's plays some russicisms" and "not absolutely was firm in translation of the original" (Levin \& Fedorov, 1960).

In the second half of the XIXth century in Russia the aspiration to an art reconstruction of foreign poetry in the form corresponding to the original gradually amplified. This thought in the concentrated form was expressed in 1891 by the anonymous author of "Knizhki Nedeli" ("Books of a Week"): "Contrary to the extended opinion $\langle\ldots>$ that it is better to translate classics by prose, than by verses, we think absolutely opposite. Any prose translation of a poetic work will never give the real idea of it" (Books of Week, 1891). The anonymous critic proved the statement by loss in prosaic translation of that unique "bouquet" that makes "the life of any graceful work and without which it is similar to the exhausted wine" (Books of Week, 1891).

Such position was conformable to perception of poetry and a poetic translation of literary critics of the XXth century, in this connection one can remember M.M.Bakhtin's thought that "only the poetry exploits the language" (Bakhtin, 1975), also the judgment of the known interpreter and the philologist specialized in Spain literature S.F.Goncharenko writing that "the poetic text pressed by rhythmic, phonic and metaphorical systems forms as if a special 
supersemantic plasma clot in which each element (whether it is a whole line, a word, a morpheme or even a phoneme) is interfaced on a vertical and horizontal line to each other element and finds trembling, as a moonlight, additional and multilayered value" (Goncharenko, 1999). And it is valid, practically all Russian prose translations of foreign poetry made in the second half of the XIXth century (P.A.Kanshin, A.L.Sokolovsky, etc.) combined such opposite shortcomings as inaccuracy and literality (Notes of Imperial academy of Sciences, 1886), and also were noted in abuse of the device of transferring of the foreign language author to the Russian soil (Nelyubin \& Hukhuni, 2008).

The most traditional views on poetry translation of that time were expressed by the outstanding scientist and at the same time the translator from Italian A.N. Veselovsky who considered that a translator has to combine qualities of a scientist and an artist as well, and that the translation art of a foreign author has to become the subject of study, as well as "the poetic experience of the translator-artist" (Notes of Imperial academy of Sciences, 1886). He noted that "trifles are important quite often - especially a metre, the use of a rhyme in verses" (Notes of Imperial academy of Sciences, 1886), but grave, semantic essential fragments of the description "give the translator's measure, indicate his sense of style" that is even more considerable requirement, "than adherence to a metre and a rhyme" (Notes of Imperial academy of Sciences, 1886). Proceeding from told, A.N.Veselovsky made the main demand to the translator - to transfer the work in such a way as it is, without embellishing and without changing it: "It is necessary to be able to be trivial and a poet as well to master a measure and a feeling of harmony of that and another in a foreign language and our modern" (Notes of Imperial academy of Sciences, 1886). In other words, the poetic translation has to become the living twin of the original and to be actively joined in the literary process in a target language. For preservation of the main thing - the reproduction of independent poetic value of the original text - the translator is obliged to endow proximity in minor details, separate art nuances, thus remaining a sympathetic poet and a sensitive philologist. A.N.Veselovsky condemned subjectivity and arbitrariness of the translator which covers "the poet whom he wants to transfer; to please his own verse omits the verses of a translated author, changes a metre, develops and reduces the text according to his own discretion" (Notes of Imperial academy of Sciences, 1886).

The principles which are scientifically formulated by A.N.Veselovsky found reflection in works of many talented translators of the second half of the XIXth century who refused from the free interpretations typical of the previous texts and attempts of distribution of the original texts and aspiring to a conciseness when reconstructing the original and accuracy in transferring the manner of execution of a verse, its figurativeness. And to this general norm, on K.I.Rovda's supervision, Min's interpretations fully corresponded in particular his translation of the historical chronicle of Shakespeare "King John" (Rovda, 1965). In this regard the problem of refraction of supervision of scientists-predecessors on the creative works of any translator of D.E.Min's epoch which wasn't drawing before special attention is actual.

\section{Materials and Methods}

The original and translated poetic texts, articles of the Russian literary criticism of the second half of the XIXth century, information from the Russian biographic and reference bibliographic editions of the second half of XIXth - the beginnings of the XXth century, the epistolary and memoirs sources comprehending literary activity of D.E.Min became a material for the analysis.

The theoretical and metodological base of the research is based on works of classics of Russian literary criticism, for example, Alexey N. Veselovsky (Veselovsky, 1896), V.M.Zhirmunsky (Zhirmunsky, 1966), M.M.Bakhtin (Bakhtin, 1975), works of researchers of the international literary relations, first of all, of representatives of the Leningrad comparative-historical school - M.P.Alekseev (Alekseev, 1931), R.M.Gorokhova (Gorokhova, 1966), Yu.D.Levin (Levin, 1985), K.I.Rovda (Rovda, 1965), etc., works on problems of Russian-English literary and historical and cultural interaction (N.Ya. Dyakonova (Dyakonova, 1978), A.A.Elistratova (Elistratova, 1956), N.P.Mikhalskaya (Mikhalskaya, 1995), L.I.Nikolskaya (Nikolskaya, 1972), S.A.Orlov (Orlov, 1939), B.G.Reizov (Reizov, 1966), etc.) theory and history of a literary translation (M.L.Gasparov (Gasparov, 1992), S.F.Goncharenko (Goncharenko, 1999), P.M.Toper (Toper, 2001), A.V.Fedorov (Fedorov, 1983a; Fedorov, 1983b), R.R.Tchaikovsky (Tchaikovsky, 1997), etc.), history of the Russian translated fiction (A.A.Asoyan (Asoyan, 1990), G.R. Gachechiladze (Gachechiladze, 1972), I.N.Golenishchev-Kutuzov (Golenishchev-Kutuzov, 1971), L.L.Nelyubin \& G.T.Hukhuni (Nelyubin \& Hukhuni, 2008), etc.).

Not numerous works of the West European researchers affecting D.E.Min's creative works in the context of the international literary relations were used - H.Buriot-Darsiles (Buriot-Darsiles, 1924), A.Engel-Braunschmidt (EngelBraunschmidt, 1973), and also by comparison of the originals and D.E.Min's translations - authoritative editions of works of English writers (Byron, 1837; Shakespeare, 1856; Morris, 1868; Buchanan, 1882; Burns, 1886; Milton, 1900; Shelly, 1901). 


\section{Results}

Without being a professional writer, Min didn't consider it necessary to state the translation principles in details. Nevertheless, researching his works and comments to them, it is possible to reveal several bases of his translation activity.

First Min-translator differed in aspiration to an exact reconstruction of a verse form of the original that prove not only his translations, but also the author's notes to them. For example, about the translation of "Hell" by Dante Min wrote: "...I decided to translate the part of the immortal creation to Russian by the original metre..." (Dante, 1855), concerning the translation of a fragment of "Don Juan" of J.G. Byron marked out : "Except for the few stanzas $\langle\ldots\rangle$ all episode is translated completely and besides by the original metre..." (Min, 1881), in the letter to N.V. Gerbel on July 2, 1854 in connection with the translation transfer of "The song about a bell" of F. Schiller specified: "In the translation I observed the original metre everywhere..." (Min, 1854).

Second Min adhered to the principle of obligatory performance of a rough translation with the subsequent finishing meaning more exact transfer of the original and improvement of a poetic verse. So, in completely unpublished letter to M.N.Longinov on February 23, 1863 which is nowadays stored in the hand-written department of the Russian Literature Institute he reported: "Final finishing of my verses always made for me the most important and most difficult part of all my work on which I always used more time, than on the translation" (Levin, 1985). In the preface to the unabridged edition of "The divine comedy" by Dante in his translation which was issued in $1902-1904$ it was noted not only the scale of activity of the translator, but also his insistence to itself causing need to address to seemed complete work again and again: "It is necessary to see D.E. Min's manuscripts to judge what a giant work it is as the translator considered each expression, each word, unmercifully destroying the ready translation searching the best image of thought of the creator of "The divine comedy"' (Dante, 1902 - 1904). As we can see, not only the translations prepared for printing were being edited but also already published ones. In particular, after emergence in press of "Hell", continuing work on other parts "The divine comedy" - "Purgatory" and "Paradise", Min again returned to the first part of the great work, sought to translate more precisely and more clearly the thoughts and artistic images of Dante, exempted the text from excessive archaisms to what changes in the translations from the edition to the edition testified. For example, according to R.M.Gorokhova and M.P.Alekseev's calculations who compared the song V of "Hell" in editions of 1843, 1853 and 1902 111 from 142 verses of the initial version underwent a partial or radical change (in 1853 - 53 verses, in 1902 - 58 verses more) whereas invariable were only 31 verses (Alekseev, 1931; Gorokhova, 1966). Yu.D.Levin gives some other figures that, however, doesn't change the main point: in the publication of 185565 verses, in a final version - 55 verses more were changed, besides from earlier changed 51 verses are remade, i.e. invariable were only 22 verses (Levin, 1985). The translation of a fragment of Byron's "Don Juan" printed for the first time in 1852 was essentially edited describing death of the Spanish ship "Santa Trinidada" (Min, 1852), - in comparison with the corresponding episode of a final version of 1881 the change of 254 from 672 verses is obvious, i.e. more than a third of the text.

Yu.D.Levin noted the accuracy of Min's translations which from time to time were coming nearer to interlinear, but at the same time precisely transferring the stylistic features of the original (repetitions, tropes etc.) and as a proof he gave examples from the original text of the song $\mathrm{V}$ of a hell (Francesca de Rimini's story) and from the Russian translation which was completely recreating its stylistics. Dante's three terza rimas contained an anaphor of "amor" ("love"): "Amor, che al cor gentil ratto s'apprende" (V, 100), "Amor, che a nullo amato amar perdona" (V, 103), "Amor condusse noi ad una morte" (V, 106), and in verse 103 there were two more cognate words of "amato" and "amar"; in Min's translation features of the original text are extremely kept: "Love, whose power we learn easily", "Love ordered us to love loving persons", "Love in one grave brought us together" (Levin, 1985). It is simple to find similar examples on the material of the translations of other works. So, in the second part of Byron's "Don Juan" by means of five comparisons sleeping Juan is described: "Hush'd as the babe upon its mother's breast, / Droop'd as the willow when no winds can breathe, I Lull'd like the depth of ocean when at rest, / Fair as the crowning rose of the whole wreath, / Soft as the callow cygnet in its nest" (Byron, 1837) [Is silent as the child on a breast of the mother, / Is inclined as a willow, when there is no wind, / It is quiet as an ocean chasm during a calm, / Is great as the rose crowning a garland / It is gentle as a young swan in the nest]; in his translation Min extremely precisely recreates both parallel designs of an octave, and a figurative row: "Is silent as the baby on a native breast, / Is inclined as a willow in the scorching heat of summer, / Is imperturbable as the sea before a thunder-storm, / Is beautiful as a rose of a magnificent bouquet, / And is gently young as a young swan" (Min, 1880).

Third beginning his work on the translation Min previously studied the personality and works of the elected author that was for the first time noted by M.L.Mikhaylov writing that in a modern for him literature "together with $<\ldots>$ a sad disrespect for great writers thorough study of them that is due to such strong, grave and high-gifted works as $<\ldots>$ Min's 
translations of Dante, Krabb and Schiller" (Mikhaylov, 1958; Levin \& Fedorov, 1960). In relation to "The divine comedy" the "genetics" of Min's translation activity was revealed by A. A. Asoyan reporting that Min "relied on the experience of the German dantologs and such poets as K. Witte, Wagner, K. Kannegiser, and especially A. Kopish and Filalet <a literary pseudonym of the Saxony King John>" (Asoyan, 1990). In the other part of the research A. A. Asoyan recognized the influence on Min not only "studies of dantologs of the German school", but also creativity of compatriots of great Dante L. Da Ponte, J. Volpi, P. Venturi, P. Fratichelli, J. Skartazzini's works, and also the works of commentators of the last years - R. da Imola, K. Landino, B. Daniello, etc. (Asoyan, 1990).

Min's creative choice of the works of the foreign authors deserving interpretation was also based on studying of works of Russian critics and translators predecessors. So, he translates Dante thanks to the thesis of S.P.Shevyrev "Dant and his lifetime. Research about "The divine comedy"', printed in "Scientific notes of Imperial Moscow university" in 1833 - 1834, and J. Krabb's creativity drew his attention in connection with a series of articles of A.V.Druzhinin "George Krabb and his works", printed in Nekrasov's "Sovremennik" ("Contemporary") in 1855 - 1857 (llyazova, 2010).

Min's ideological positions as a translator are rather confused and accurately aren't formulated that doesn't allow to refer his creativity to this or that ideological direction in the light of literary fight of the $1850-1870$ s. On the one hand, he was the constant author of "Russkiy Vestnik" ("Russian Messenger"), the magazine with accurately expressed conservative position entering continuous polemic with editions of democratic orientation. In "Russkiy Vestnik" ("Russian Messenger") the vast majority of Min's translations in particular relating to the most considerable period of his activity the end of the 1850s - the beginning of the 1880s - was published. At the same time Min's cooperation with "Russkiy Vestnik" ("Russian Messenger") was caused not so much ideologically but by confluence of a number of circumstances: working as an assistant at a hospital clinic of Moscow University, Min (during that time already a doctor of medicine) was the second editor of "Vrachebniy Zhurnal" ("Medical magazine") since 1851; the same year M.N.Katkov was accepted to a position of the editor of the university newspaper "Moskovskiye Vedomosti" ("Moscow News") whose "Russkiy Vestnik" ("Russian Messenger") in many respects grew up from "Moskovskiye Vedomosti" ("Moscow News"); Min and M.N.Katkov who yet didn't refuse many liberal values and representations were familiar among themselves, working in one collective, but also cooperated - in "Moskovskiye Vedomosti" ("Moscow News") one of Min's translations of J.Krabb was issued (Min, 1857). Subsequently M.N.Katkov endured evolution of the ideological views that didn't push away from him in many respects apolitical Min who saw in the editor of "Russkiy Vestnik" ("Russian Messenger") a friend capable to help with the publication of the complete translations. Besides Min's status, his high positions that he held at Moscow University, hardly assumed his transition to positions of Nekrasov's editions.

On the other hand, in Min's translations there is no distinct sense of conservatism. Moreover the translator aimed to put and solve many problems through a prism of a social component of human life. In particular, in his translation of A.Tennyson's poem "Lady Klara Vir de Vir" the aspiration "to induce representatives of the upper class to think about destinies of poor people" was expressed, the appeal "to leave love joys and "to go to the people" sounded - to help the poor, to teach orphans reading and writing and needlework" (Chernin, 2009). Min wasn't antipathetic to democratic criticism, - about him, though it is a little, but positive, M.L.Mikhaylov, N.G.Chernyshevsky, N.A.Dobrolyubov wrote who saw his merits in interpretation of poems of a social orientation (F. Schiller's "The song about a bell", "Artists"). But also here Min's civic position can be called precisely weighed and moderated: he "naturalistically" recreates the terrifying poverty pictures, however is guided thus by the original texts of the poet-priest J. Krabb known for his loyalty to the authorities and nonresistance to the evil; he addresses to works of the radical English author U.Morris, but thus translates a fragment of his earliest work - "Earthly paradise" created under the influence of Pre-Raphaelites and which isn't bearing in itself intonations typical of later works.

\section{Discussion}

In ideological fight of the time Min in many respects appeared in an isolated situation as aspired not so much to the triumph of these or those ideas, but to the maximum objectivity at perception and interpretation of the translated text. Advantages of Min's translations are obvious as both in semantic (what is told), and in stylistic (how is told), and in pragmatical (what reaction causes that is told) aspects they qualitatively give the original plans, though don't reach an ideal accuracy. In S.F.Goncharenko's opinion, the absolutization of one of three specified aspects "leads to a certain type of literalism: semantic (the most consistently realized in word for word translations), stylistic (in other words, to "a translation formalism" at which exact translation of minor style features of the original destroys general impression) or pragmatical ("inducement on our customs")" (Goncharenko, 1999). Min's translations are rather poetic however in desire of the translator as much as possible to approximate to the original in the verbal and stylistic relation the aspiration to transform the poetic text in "spatial", originally poetic is notable. Min was one of those translators of the second half of the 
XIXth century who aimed to recreate the unity of the contents and the form of the original, to reproduce it as an alive and complete poetic organism, but not as a dead photocopy or the lifeless scheme, even if also exact in the smallest details.

\section{Conclusions}

Complexity of studying of Min's creative activity is in many respects caused by lack of the author's works capable to give an idea of his translation principles. And still these principles, despite some "smoothness" of Min's professional ambitions in the field of the translation, with all evidence appear and in texts of the translations, and in author's comments to them, and in responses of literary criticism; this preliminary studying of the foreign author and works of the Russian translators predecessors, observance of a verse form of the original, invariable improvement of language and style of the translation, avoiding of ideological implication for the sake of objectivity in the interpretations. The advantage of Min's translations is in harmonious transfer of original author's plans in semantic, stylistic and pragmatical aspects. The translator seeking for the fullest reflection of the foreign works in Russian managed to avoid frequent distortions towards literalism or free translation that left the original the fact of the foreign literature, without turning it into the original work of the native author. Min's "private" interest in translation in general was an essential contribution to professionalizing of a poetic translation in Russia of the second half of the XIXth century.

D. E. Min is a significant figure in the context of the history of the Russian poetic translation of the second half of the XIXth century, and therefore studying of his activity promotes accumulation of research data for the solution of a major scientific problem - creation of fundamental history of the Russian literary translation. In this regard noted discrepancy of ideological searches and D. E. Min's aspirations serves as evident argument against traditional perception of Russian translation of the 1860s - the 1870 s as the only process of fight of representatives of two ideological camps noble and liberal and revolutionary-democratic. This process, indisputable, is important, however considerable part of the Russian translators, including D. E. Min, separating from it, without adjoining directly one of the camps, achieved significant results first of all thanks to the ability of a good feeling of characteristic features of the interpreted originals, to refuse from the introduction into them of his own thoughts and ideas to please to actual tendencies of public life.

\section{Acknowledgements}

The research has been carried out within the project on a grant of the Russian President of MD-5818.2015.6 "Textual criticism and poetics of the Russian literary translation of XIX - the beginning of the XXI century: reception of English poetry of the Victorian era in synchronism and diachronism".

\section{References}

Alekseev, M.P. (1931). Problem of literary translation. Collection of works of Irkutsk State University, XVIII, Vol. 1. (pp. 149-196). Asoyan, A.A. (1990)."Honor the greatest poet ...". Destiny of "The divine comedy" of Dante in Russia. Moscow: Book.

Bakhtin, M.M. (1975). Questions of literature and esthetics. Researches of different years. Moscow: Fiction.

Books of a Week (1891). "Hamlet" in Russian translations. Books of a Week, (Vol. 11). ( pp. 231 - 235).

Buchanan, R. (1882). Selected Poems: In 5 vol. Vol. I. London Poems. London: Chatto \& Windus.

Buriot-Darsiles, H. (1924). Dante et la censure russe. Revue de littérature comparée, 4, 109-111.

Burns, R. (1886). The Complete Works: In 6 vol. Vol. 1. London: Gebbie \& Co.

Byron. (1837). Don Juan. London: John Murray.

Chernin, V. K. (2009). Russian reception of Alfred Tennyson. Thesis of the Doctor of Philology. Saratov: Saratov State University named after N. G. Chernyshevsky.

Dante. (1855). Hell. With the appendix of the comment, explanatory materials, a portrait and two pictures. Translated from It. by the metre of the original by D. Min. Moscow: University printing house.

Dante. (1902 - 1904). The divine comedy: Hell. Purgatory. Paradise. Translated from the Italian language by the original metre by $D$. E. Min [Vol. 1 - 3]. St. Petersburg: A. S. Suvorin's printing house.

Dzhivelegov, A.K. (1933). Dante Alighieri. Life and creative works. Moscow: Journal and newspaper association.

Dyakonova, N. Ya. (1978). English romanticism. Esthetics problems. Moscow: Science.

Elistratova, A.A. (1956). Byron. Moscow: Publishing house of Academy of Sciences of the USSR.

Engel-Braunschmidt, A. (1973). Deutsche Dichter in Russland im 19. Jahrhundert: N.V.Gerbel's «Deutsche Dichter in Biographien und Proben» als Zentrum der Kenntnis und Verbreitung deutscher Dichtung. München: W. Fink.

Fedorov, A.V. (1983a). Art of the translation and life of literature. Sketches. Leningrad: Soviet writer.

Fedorov, A.V. (1983b). Bases of the general translation theory (linguistic problems). (4 ed., processed and added ). Moscow: The higher school. 
Gachechiladze, G.R. (1972). Literary translation and literary interrelations. Moscow: Soviet writer.

Gasparov, M. L. (1992). Exact methods and problems of the translation. Literature and translation: theory problems. International meeting of scientists and writers (pp. 73-78). Moscow: Progress-Litera.

Golenishchev-Kutuzov, I.N. (1971). Dante's creativity and world culture. Moscow: Science.

Goncharenko, S.F. (1999). Poetic translation and poetry translation: constants and variability. Translator's notebooks, 24. (pp.107 122).

Gordon, YA.I. (1973). Heine in Russia (the 1830s - the 1860s years). Dushanbe: Irfon.

Gordon, YA.I. (1979). Heine in Russia (1870-1917). Dushanbe: Donish.

Gorokhova, P.M. (1966). Dante's "Hell" in D. E. Min's translation and imperial censorship. Russian-European literary communications. The collection of articles to the 70th anniversary since the birth of the academician M.P. Alekseev (pp. 48-55). MoscowLeningrad: Science.

Ilyazova, E.I. (2010). George Krabb's creative works in judgment of the Russian writers and literary critics in the 1820 - 1860 s. Thesis of Candidate of Philology. Saratov: Saratov State University named after N. G. Chernyshevsky.

Levin, Yu.D. (1985). Russian translators of the XIXth century and the development of literary translation. Leningrad: Science.

Levin, Yu.D. (1999). Min Dmitri Egorovich. Russian writers. 1800 - 1917. Biographic dictionary. Vol. 4 (pp. 72-73). M.: Comprehensive Russian encyclopedia; Fianit.

Levin, Yu.D. \& Fedorov, A.V. (1960). Russian writers about the translation (the XVIII-XIXth centuries). Leningrad: Soviet writer.

Mikhalskaya N.P. (1995). An image of Russia in English fiction of the IX-XIXth centuries. Moscow: Publishing house of the Moscow pedagogical state university.

Mikhaylov, M. L. (1958). Compositions: In 3 vol. Vol. 1-3. Moscow: State publishing house of fiction.

Milton, J. (1900). The Poetical Works. Oxford: Clarendon Press.

Min, D.E. (1852). Death of the Spanish ship Santa Trinidada. From Bayron's Don Juan. Moskvityanin, 5, 20, I. (pp. 191 - 212 ).

Min, D.E. (1854). The letter to N. V. Gerbel of July 2, 1854. National Library of Russia, fund 179, unit of storage 77.

Min, D.E. (1857). Town (The Borough). George Krabb's poem. Chapter $1<$ translation of the letter I "General description" >. Moscovskiye Vedomosty (Moscow news), 16 Febr. (No. 21) (pp. 93-94).

Min, D.E. (1880). Don Juan on the island of the pirate. From the poem of Lord Byron "Don Juan". Translation from English by the original metre. Russky Vestnik (Russian messenger), 152, 3 ( pp.154-209); 4 (pp. 512-558).

Min, D.E. (1881). Don Juan on the island of the pirate. From the poem of Lord Byron "Don Juan". Translated from English by the original metre by D. Min. Moscow: University printing house.

Morris, W. (1868). The Earthly Paradise. London: Hector.

Nelyubin, L. L. \& Khukhuni, G. T. (2008). The science of translation (history and theory from ancient times to the present day). (2nd ed.). Moscow: Flinta; MPSI.

Nikolskaya, L.I. (1972). Shelley in Russia (Shelley's lyrics in Russian translations of the XIX-XXth centuries). Smolensk: Publishing house of Smolensk state teacher training institute named after Karl Marx.

Notes of Imperial academy of Sciences (1886). The report on the third award of Pushkin's awards in 1886. Notes of Imperial academy of Sciences, LIV, (Vol.2).

Orlov, S. A. (1939) Burns in Russian translations. Scientific notes of Leningrad state teacher training institute named after A. I. Herzen, XXVI (pp. 225-246).

Reizov, B.G. (1966). Comparative study of literatures. Literary criticism methodology problems (pp. 171-196). Moscow-Leningrad: Science.

Rovda, K.I. (1965). Years of reaction. Shakespeare and Russian culture. (pp. 627-698). - Moscow-Leningrad: Science.

Shakespeare, W. (1856). The Plays: In 8 v. V. 4. London: George Routledge \& Co.

Shelly, P.B. (1901). The Complete Poetical Works: In 3 vol. Vol. 2. Cambridge: W. Metcalfe.

Staritsyna, Z.A. (1980). Bérenger in Russian literature. Moscow: The higher school.

Toper, P.M. (2001). The translation in the system of comparative literary criticism. Moscow: Heritage.

Tchaikovsky R. R. (1997). A poetic translation in a mirror of opinions. Magadan: Kordis.

Veselovsky, Alexey N. (1896). The western influence in new Russian literature. Moscow: Russian association of printing and publishing.

Yampolsky, I.G. (1956). Poetry of the sixties years [the XIXth century] (general review). History of Russian literature: In 10 v. Vol. VIII. Literature of the sixties years. Ch. 2. (pp. 7-55). Moscow-Leningrad: Publishing house of Academy of Sciences of the USSR.

Zhirmunsky, B.M. (1966). Verse and translation. Russian-European literary communications (pp. 423-470). Leningrad: Nauka (Science). 
ISSN 2039-2117 (online) ISSN 2039-9340 (print)
Mediterranean Journal of Social Sciences MCSER Publishing, Rome-Italy
Vol 6 No $3 \mathrm{~S} 3$ May 2015 